\title{
Anti-Corruption Disclosure Practices of Indonesia Public Companies
}

\author{
Faisal Faisal ${ }^{1}$, Andriani Saputri ${ }^{2}$, Tarmizi Achmad ${ }^{3}$, Andri Prastiwi ${ }^{4}$ \\ Master of Accounting Program, Faculty of Economics and Business, Universitas Diponegoro, Semarang
}

\begin{abstract}
This study investigates the content and determinants of anti-corruption disclosure of Indonesian public listed companies. Content analysis method will be used to extract the anticorruption information in the annual reports, stand-alone reports and websites. This study uses 40 checklist items developed by Joseph et al (2016) which is grouped into seven themes ((1) accounting disclosure for combating bribery, (2) disclosure of board and senior management responsibilities, (3) establishing human resources to combat bribery, (4) responsible business relations, (5) external verification and guarantee, (6) code of conduct, and (7) whistle-blowing) to measure the extent of anti-corruption disclosure. Univariate and multivariate regression analysis will be applied to test the determinants of anti-corruption disclosure. The results show that the effectiveness of internal control systems to counter bribery and the company subjects the internal control systems are the most items disclosed by company (100\% / 243 firms), followed by disclosure of company's charitable contribution and sponsorship (62.3\% / 147 firms) and the prohibits the offer or receipt gifts, hospitality or expenses (60.5\% / 147 firms). In terms of determinants of disclosure, size and government ownership have significant effect on anti-corruption disclosure. This study contributes to the accounting and business literature by providing a more comprehensive insights of anti-corruption disclosure practice from the emerging country. The finding of is expected can be beneficial to regulators in determining policies regarding anti-corruption practices in public lister companies.
\end{abstract}

Keywords: CSR, Disclosure, Anti-corruption, content analysis, Indonesia 